\title{
論文
}

\section{Heat Effect and Temperature Rise in Circular Tube Viscous Flow}

\author{
by
}

\author{
Akira OoIwa and Kimio Kurase
}

(National Research Laboratory of Metrology, 10-4, 1-chome, Kaga, Itabashi-ku, Tokyo 173)

The viscous heat effect on the fluid temperature is investigated in circular tube flow. Approximate mathematical solutions are given for the temperature distribution of fluid over the cross section of a circular tube and also for the temperature rise of fluid along the tube in consideration of heat conduction through the tube wall.

In the case of liquid flow, the temperature rise $\Delta T$ at the exit of the tube is related to the pressure drop $\Delta p$ through the tube by the following approximate equation.

$$
\begin{aligned}
& \Delta T=A \times\left(1-\exp \left[\frac{1}{A c \Delta p}\right]\right) \times \Delta p^{2}, \\
& \text { where } \quad \begin{aligned}
A= & \frac{a^{4}}{16 \eta l^{2}}\left(\frac{\ln (b / a)}{\kappa_{c}}+\frac{5}{24 \kappa_{f}}\right), \\
a & : \text { internal radius of tube } \\
b & : \text { external radius of tube } \\
l & : \text { length of tube } \\
\kappa_{c} & : \text { thermal conductivity of tube } \\
\kappa_{f} & : \text { thermal conductivity of liquid } \\
c & : \text { volumetric heat capacity of liquid } \\
\eta & : \text { viscosity of liquid. }
\end{aligned}
\end{aligned}
$$

The temperature rises calculated by this equation generally agree with those obtained by $\in \mathrm{x}$ periments.

In the case of gaseous flow where the sample gas is regarded as an ideal gas, it is concluded theoretically that the heat energy due to viscous resistance is spent in compensation for the reduction of internal energy due to the bulk expansion of flowing gas with the decrease of pressure, and consequently, temperature of flowing gas is kept constant.

\section{細管中の粘性流動による発熱と試料の温度上昇}

$$
\text { 大岩彰・倉瀬公 男* }
$$

（原稿受俳：1979年1月10日）

\section{1. 緒言}

細管法による流体の粘度測定は, 代表的な測定法として古くか ら重視され，特に絶刘測定と言われる実験の多くにはこの方法が

* 計量研究所 東京都板橋区加賀 1 丁 110 番 4 号
用いられて来た，細管法によって流体の粘度を测定する際の閭題 点には, 管端の影響, 運動エネルギーの補正, 気体に打ける管壁 での滑りの影響等があるが，これらの閣題についての議諭は，今 までに多くなされている。ここでは，上記以外の間题点として， 液体扣よび父体の粘性流動による登熱の効惩を取り上げて考察椧 
討した。円筒細管*中に抢ける粘性流動に伴 5 発熱の問題につい ては，過去何人かの人々によって検討されているが(1) 文，その多 くは境界条件として，管内壁に扣いて等温状態もしくは断熱状態 を仮定して，管内の温度分布や温度上年量を求めている。これら の結果は，管材質の熱伝導率を，無限大もしくは零と見なせる場 合に適用できる。しかし，管材質の熱伝導率が試料流体の熱伝導 率と同程度の大きさをもつ場合, または管の肉厚が管内径に比し て無視できない場合には，そのまま適用することはできない，そ こで筆者らは, 粘性発熱による流体の温度上昇に関し, 管の熱伝 導が無視できない場合について理諭的考察を行った。流体が液体 の場合については, 考察結果と実験結果との比較を行い, 考察の 妥当性を確かめた。また，流体が気体の場合については，粘性流 動に伴万登熱の效罢に関して, 細管中の気体粘性流を报っている 文献の多くが言及していないので，ここに合わせて諭ずる。

\section{2. 理 論}

理諭式を立てるために, Fig. 1 亿示すよ 5 に内半径 $a$, 外半径 $b$, 長さ $l$ の細管に効して軸上飞 $z$ 軸を持ち, 半径方向に $r$ 軸を もつ円筒座標を当てはめる。管中を流れる流体の運動方向と $z$ 軸 の方は一致しているとする.

対象系を数学モデルとして理諭的に解くために, 以下に述べる 幾つかの仮定を設ける.

1. 流体はニュートン流体である.

2. 管中の流れは層流で定常状態にある. また, 熱的にも定常 状態にある。

3. 管端効杲については無視する。

4. 管壁での流体の滑りはない.

5. 流体速度は $z$ 方向成分のみである。

6. 重力等の外力の影響は無視できる.

7. 粘度打よび熱伝導率は. 管中に扔いて一樣かつ一定である.

8. 管外壁温度と流入時の流体温度は一致し, 一定である.

9. $z$ 方向への伝導による熱伝這は無視する.

10. 液体流の場合には, 非圧縮性流体と見なせる。氮体流の場 合には，理想気体と見なせる。

\section{$2 \cdot 1$ 細管内の流速分布}

仮定 1 〜 により，管内の流れはポアズイユ流として表され

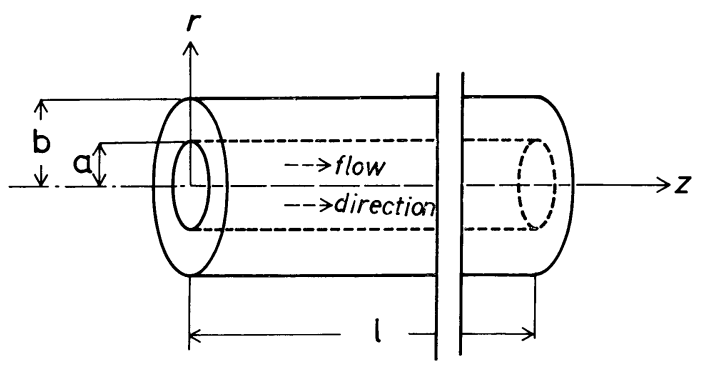

Fig. 1 Dimensions and cylindrical coordinates of a circular tube.

* 本論文では, $1 \mathrm{~mm}$ オーダーの内径を持つ細管を想定してい るが，内径がこれよりも大さい，または小さい円筒管につい ても, 流れが層流条件を満足していれば, 本渝文の議諭は,

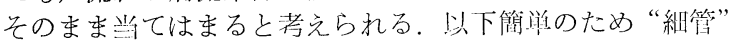
また弾に“管”と表く.
る。ポアズイユ流に拈ける管内の流速分布 $u(r)$ と体積流量 $q$ は. 次式で表せる.

$$
\begin{aligned}
u(r) & =-\frac{1}{4 \eta} \frac{d p}{d z}\left(a^{2}-r^{2}\right) \\
q & =-\frac{\pi a^{4}}{8 \eta} \frac{d p}{d z}
\end{aligned}
$$

液体については, 流速および体積流量は $z$ 万向で変化しない。 気体については，流れによる圧力の低下とともに体積膨張するの で, 流速, 体積流量ともに位置 $z$ の関数になり, 下流に行くほど 增加する。このとき, 式(1)と(2)の両式は近似式と考兄られ, 気体 流の膨張速度が大きくなる汪どこの近似は悪くなる。

\section{$2 \cdot 2$ 熱エネルギー方程式}

一般に，物質の温度を決める要素は熱輻射を別にすれば，次の 3つが考えられる。

（1）登熱または吸熱流動摩擦, 化学反応, 膨張収縮等に よって熱エネルギーと他のエネルギーとの間の変換が行われる. この省位体積当たりの登熱量をので表す。

（2）熱伝導温度勾配 $\nabla T$ があると熱伝導率 $\kappa$ に比例する 熱流束 $\boldsymbol{W}=-\kappa \nabla T$ が生ずる。

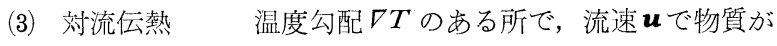
移動すると，これは温度変化 $-\boldsymbol{u} \cdot \nabla T$ をもたらす。

以上の 3 つの要素をまとめて, 次の方程式が得られる.

$$
\begin{aligned}
\frac{\partial T}{\partial t} & =\frac{1}{c}(\sigma-\operatorname{div} \boldsymbol{W})-\boldsymbol{u} \cdot \nabla T \\
& =\frac{1}{c}\left(\sigma+\kappa \nabla^{2} T\right)-\boldsymbol{u} \cdot \nabla T
\end{aligned}
$$

ここに, cは単位体積当たりの熱容量である.

ここで, Fig. 1で示される細管について式(3)を当てはめて, そ の定常状態に扣ける解を求めてみる. 仮定 $4 \sim 8$ 亿より温度 $T$, 流速 $u$ 执よび発熱 $\sigma$ は $(r, z)$ で決まる同一円周上では同じ值を 持つと考光られるので，式(3)は次式化変形できる。

$$
\frac{\partial T}{\partial t}=\frac{1}{c}\left[\sigma+\kappa\left\{\frac{1}{r} \frac{\partial}{\partial r}\left(r \frac{\partial T}{\partial r}\right)+\frac{\partial^{2} T}{\partial z^{2}}\right\}\right]-u \frac{\partial T}{\partial z}
$$

定常状態 (仮定 2 ) の場合, $\partial T / \partial t=0$ であるから, 式(3) の 左辺は零で置き換兄られる。 また，管径に比べて管長が充分に大 きい場合は， $z$ 万向の伝導熱量は， $r$ 方向の伝導熱量に比べて小 さく, 温度分布に与える影響は無視できる（仮定 9 ）と考えられ る. 以上の点を考慮して, 細管内部等の温度分布を与光る方程式 を導くと次のようになる。

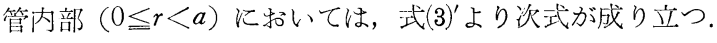

$$
0=\frac{1}{c}\left\{\sigma+\kappa_{f} \frac{1}{r}-\frac{\partial}{\partial r}\left(r \frac{\partial T}{\partial r}\right)\right\}-u \frac{\partial T}{\partial z}
$$

ここに， $\kappa_{f}$ は流体の熱伝導率である.

管部 $(a \leqq r<b)$ に扔いて. 登熱执よび娰流が無い $(\sigma=0, u=0)$ ので，管単位長さあたりの管壁を通しての流出熱舅 $L$ を積分定数 として次式を得る。

$$
L=-2 \pi \kappa_{c} r \frac{\partial T}{\partial r}
$$

ここに， $\kappa_{c}$ は管材質の熱伝導率である.

管外部 $(b \leqq r)$ 飞执いては, 温度一定 (仮定 8$)$ なので, 次式 が成り立つ。

$$
T(r, z)=T_{0} \text { (一定) }
$$

\section{$2 \cdot 3$ 発熱と温度上昇}

細管内に層流条件を満足する流れがあるとき，管外壁と流入時 
の流体の温度が, 一定に保たれているとしても, 粘性流動に伴 5 発熱によって, 流体温度は変化する事が考兄られる. 気体の昜合 は, この登熱の効寒に加えて, 圧力低下に伴了膨張吸熱の効果が ある。それぞれの場合について検討してみる。

\section{$\mathbf{2} \cdot \mathbf{3} \cdot \mathbf{1}$ 液体における流動発熱の効果}

粘性の定義により, 発熱量 $\sigma は$ 粘度 $\eta$ の液体に詨して, 次式で 与えられる。

$$
\sigma=(\text { 剪断応力 }) \times(\text { 速度勾配 })=\eta\left(\frac{\partial u}{\partial r}\right)^{2}
$$

流速 $u$ は式(1)で表されるから.これを用いて $\sigma$ は次式で表せる.

$$
\sigma(r)=\frac{1}{4 \eta}\left(\frac{d p}{d z}\right)^{2} r^{2}
$$

上式(8)を用いて単位時間，単位管長当たりの発熱量 $Q$ を求めると 次式を得る。

$$
Q=\frac{\pi a^{4}}{8 \eta}\left(\frac{d p}{d z}\right)^{2}=-\frac{d}{d z}(p q)
$$

上式(9)の最右辺の項 $-d(p q) / d z$ は, 压力 $p$ によって力学的にな される，単位時間当たりの仕事量を管長方向 $z$ で微分したもので ある。

式(8)，(9)を2・2で得られた結果に適用して，平衡状態に括ける 温度分布を求める。流入時の流体温度は管外部の雾囲気温度 $T_{0}$ と一致している(仮定 8 )が，流れるに従って流体温度は上昇し， 充分な距離を流れると, 流体内で粘性流動によって発生する熱量 と管内外壁間の温度差によって，管壁を通して管外へ流出する熱 量が平衡する点まで澾する。平衡に達すれば，管軸方向での温度 変化は無くなり, $\partial T / \partial z=0$ が成り立つ. 実際問題としては, 平 衡状態に至るまでの温度上界過程について知ることが重要である が，その前に平衡状態に扣ける温度分布を求める。

温度分布を与える方程式は，式(4)，(5)扣上び式(6)飞扔いて， $\partial T / \partial z=0, L=Q$ と置くことにより得られ，次の諸式で表され る.

管内部 $(0 \leqq r<a): \sigma=-\kappa_{f} \frac{1}{r} \frac{\partial}{\partial r}\left(r \frac{\partial T}{\partial r}\right)$ (10)

管部 $(a \leqq r<b): \quad Q=-2 \pi r \kappa_{c} \frac{\partial T}{\partial r}$

管外部 $(b \leqq r): T=T_{0}$ （一定）

$r=0$ で $\partial T / \partial r=0$ とい5条件で, 上式 10$)$ ，(11)扣よび式(12)を解い て平衡状態に扣ける温度分布 $T(r)$ を求めると, 次式の結果を得 る.

$$
T(r)= \begin{cases}T_{0}+\frac{Q}{2 \pi \kappa_{c}} \ln \frac{b}{a}+\frac{Q}{8 \pi \kappa_{f}}\left(1-\frac{r^{4}}{a^{4}}\right) & (0 \leqq r \leqq a) \\ T_{0}+\frac{Q}{2 \pi \kappa_{c}} \ln \frac{b}{r} & (a \leqq r \leqq b) \\ T_{0} & (b \leqq r)\end{cases}
$$

この平衡状態に怙ける温度分布を模式的に示したのが Fig. 2 であ る.

管内断面を通過する流体の平均温度 $T_{a}$ を次式

$$
T_{a}(z)=T_{0}+\Delta T=\frac{1}{q} \int_{0}^{a} T(r, z) u(r) \cdot 2 \pi r d r
$$

で定義すると，平均温度上昇量 $\Delta T(z)$ は $T_{a}-T_{0}$ で表される。 平衡状態に怙ける平均温度上杽量 $\Delta T_{i}=\Delta T(z \rightarrow \infty)$ は, 式(13)の 結果を用いて次式のように書ける。

$$
\Delta T_{\iota}=\Delta T_{e c}+\Delta T_{e f}=\frac{Q}{2 \pi}\left(\frac{\ln (b / a)}{\kappa_{c}}+\frac{5}{24 \kappa_{f}}\right)
$$

ここに， $\Delta T_{e c}$ と $\Delta T_{e f}$ はそれぞれ平衡状態に括ける管内外壁間

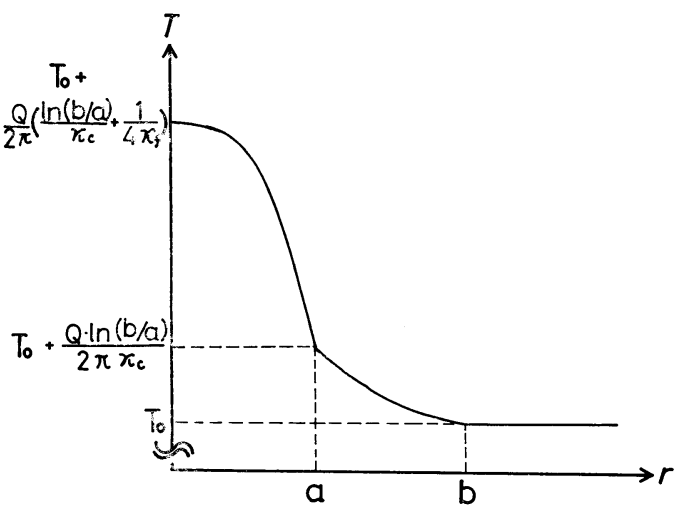

Fig. 2 Temperature distribution over the cross section of a tube with liquid flow, when viscous heat supply and heat drain through the tube wall by conduction are in equilibrium.

の温度差と，管内壁温度と液体平均温度の差である.

次いで，温度上昇過程について検討してみる，管長が充分長け れば，温度 $T_{0}$ で流入した流体は，流出端至るまでに平衡状態 に奎するはずである。しかし，実際には管の長さが充分でなく， 平衡状態に達する前の温度上昇過程の状態で流出して来ると考兄 られる。そこで，温度上升量と管長との関係を検討，評価する。 温度上昇過程见打ける流体温度の上升速度は, 粘性流動に上る発 熱量 $Q$ 之管壁を通して流出する熱量 $L$ の差 $Q-L$ 亿比例すると考 えられる. 更に流体の温度が上昇するにつれて管内外壁間の温度 差 $\Delta T_{c}$ が大きくなり，流出熱量 $L$ は $Q$ に近付いて行く，この議 論を定式化すると次の方程式が導かれる.

$$
\frac{1}{c}(Q-L)-q \frac{\partial T_{a}}{\partial z}=0
$$

ここに, $T_{a}$ は式(14)で定義される平均温度である。式(16)は，式(4) の管内断面にわたる積分形である。一方, 流出熱量 $L$ は式(5)を用 いて. 管内外壁間の温度差 $\Delta T_{c}$ と関係付けられ，次式で表せる.

$$
L=\frac{2 \pi \kappa_{c}}{\ln (b / a)} \cdot \Delta T_{c}
$$

式(16)の方程式を解くためには，更に管内外壁間の温度差 $\Delta T_{\text {。 }}$ 之平均温度 $T_{a}$ の関係, すなわち $\Delta T_{c}$ と $\Delta T_{f}\left(=T_{a}-T_{0}-\Delta T_{c}\right)$ との関係が決まらなければならない，付録にある計算機による数 值計算の結果汇よると，温度上年過程で， $\Delta T_{f} / \Delta T_{c} \propto \Delta T_{c}$ なる 関係が核涪成り立っている，そこで， $\Delta T_{f} / \Delta T_{c}=\alpha \cdot \Delta T_{c}$ と置き 式(15)，(17)を用いて，方程式(16)を境界条件 $\left(z=0\right.$ で $\left.\Delta T_{c}=0\right)$ で解 いて，平均温度上昇量 $\Delta T$ を与兄る式を求めると次式を得る.

$$
\Delta T=\Delta T_{c}\left(1+\alpha \cdot \Delta T_{c}\right)
$$
ここに,

$$
\alpha=-\frac{1}{\Delta T_{c c}} \frac{5 \kappa_{c}}{24 \kappa_{f} \ln (b / a)}
$$

また，

$$
\begin{aligned}
\Delta T_{c} & =\Delta T_{c c}\left(1-\exp \left[-\frac{z}{z_{01}}-\frac{\Delta T_{c}}{\Delta T_{0}}\right]\right) \\
z_{01} & =-\frac{c a^{4}}{16 \eta} \frac{d p}{d z}\left(\frac{\ln (b / a)}{\kappa_{c}}+\frac{5}{12 \kappa_{f}}\right) \\
\Delta T_{0} & =\frac{a^{4}}{16 \eta}\left(\frac{d p}{d z}\right)^{2}\left(\frac{12 \kappa_{f} \cdot \ln (b / a)}{5 \kappa_{c}}\right) \cdot\left(\frac{\ln (b / a)}{\kappa_{c}}+\frac{5}{12 \kappa_{f}}\right)
\end{aligned}
$$

上式(18)によって温度上昇量 $\Delta T$ を求めるためには, 式(19)を用い て $\Delta T_{c}$ を算出しなければならないが，武(19)は $\Delta T_{c}$ について陰関 
数になっており、計算機等を用いないかぎり $\Delta T_{c}$ を容易に求める ことはできない，管部の熱伝導率が比較的小さいか，または管肉 厚が大きく，管部の温度差 $\Delta T_{c}$ が管内流体の温度差 $\Delta T_{f}$ に対し て大きくなる場合については， $\Delta T_{f} / \Delta T_{c}$ の評価䛊差が，温度上 昇速度に与える影響は，相詨的に小さくなると考觉られる。そこ で, 表式を簡単にするために $\Delta T_{f} / \Delta T_{c}=$ 一定之置いてみる。 こ の関係は，平衡状態に扣いて成立するもので，平衡状態から離れ た温度上昇過程にあるほど実際との差が大さい. 式(18) と(19)を求め たときと同様にして， $\Delta T_{f} / \Delta T_{c}=$ 一定の条件で式(16)を解くと， 温度上升量 $\Delta T$ は次式で与えられる。

$$
\Delta T=\Delta T_{e}\left(1-\exp \left[-\frac{z}{z_{02}}\right]\right)
$$

ここに,

$$
\left.z_{02}=-\frac{c a^{4} d p}{16 \eta} \frac{\ln (b / a)}{d z}+\frac{5}{24 \kappa_{f}}\right)
$$

上式(20)を用いて，管流出端に㧊ける流体の温度上年量 $\Delta T_{l}$ を 得るには，式(9)扣よび(15)を代入して，式中の变数 $z$ 拉よび $d p / d z$ をそれぞれ管長 $l$ および圧力勾配一 $\Delta p / l$ で置き換えてやれば良 い. $\Delta T_{l}$ は次式で表される。

$$
\Delta T_{l}=A\left\{1-\exp \left[-\frac{1}{A C \overline{\Delta p}}\right]\right\} \Delta p^{2}
$$

ここに,

$$
A=\frac{a^{4}}{16 \eta l^{2}}\left(\frac{\ln (b / a)}{\kappa_{c}}+\frac{5}{24 \kappa_{f}}\right)
$$

管長 $l$ が充分長ければ, もしくは差圧 $\Delta p$ が充分小さければ, 式(21)の $\exp [-1 /(A c \Delta p)]$ の項は，1飞比べて充分小さくなり， そのとき温度上昇量 $\Delta T_{l}$ は, 平衡に達した場合の温度上昇量 $\Delta T_{\text {。 }}$ に一致する。実際には管長 $l$ の長さは限られているので, 発熱量 が大きくなるにつれて平衡状態からのずれが顕著になってくる. この点を吟味するために，単位時間，単位体積当たりの平均発熱 量 $H=Q /\left(\pi a^{2}\right)$ と, 温度上年量 $\Delta T_{l}$ との関係を式(21) 上り求める.

$$
\Delta T_{l}=B H\left\{1-\exp \left[-\frac{\Delta p}{B H c}\right]\right\}
$$

$$
\text { ここに, }
$$

$$
B=\frac{a^{2}}{2}\left(\frac{\ln (b / a)}{\kappa_{c}}+\frac{5}{24 \kappa_{f}}\right)
$$

上式(22)によれば，平衡状態における温度上星量は， $\Delta T_{l}=B H$ と 表されることがわかる.

\section{$2 \cdot 3 \cdot 2$ 気体における流動発熱の効果}

気体の場合には $2 \cdot 3 \cdot 1$ の液体の場合に論じた粘性流動による 発熱に加えて, 圧力低下に伴う膨張吸熱をも考慮しなくてはなら ない，一般に，圧力 $p$ が高くなければ，理想気体として报って良 いから, 体積流量 $q$ に対して次の状態方程式が成り立つ.

$$
p q=m R T
$$

ここに, $m$ はモル流量， $R$ は気体定数である. 流れ全体を力学的 に見ると, 単位時間, 単位管長当たりの流体のなす仕事 $E$ は, 次 式のように書き表される。

$$
E=-\frac{d}{d z}(p q)=-m R \frac{d T}{d z}
$$

これは，管長方向 $z$ にいて温度 $T$ が一定であれば，外部とのエ ネルギーのやりとりがないことを示している，すなわち，上流側 から流入してくる压力によるエネルギーは, 一部粘性流動によっ て熱エネルギーに変換されるが，これは気体の圧力降下に伴う等 温膨張のために用いられ，すべて下流に伝えられていく。
発熱扣よび吸熱分布は， $r$ 方向で見て一様ではなく，管内気体 温度も流線方向で一定であるとしても，r方向で見れば不均一に なっていると考光られる。 その不均一の程度について検討してみ る。単位時間, 単位体積当たりの発熱量のは, 粘性流動による発 熱量 $\sigma_{v}$ と膨張による吸熱量 $\sigma_{p}$ の和で表される。 $\sigma_{v}$ と $\sigma_{p}$ 拈よび のはそれぞれ次式(24)，(25)扣よび式(26)で示される。

$$
\begin{aligned}
& \sigma_{v}=\frac{1}{4 \eta}\left(\frac{d p}{d z}\right)^{2} r^{2} \\
& \sigma_{p}=u \frac{d p}{d z}=-\frac{1}{4 \eta}\left(\frac{d p}{d z}\right)^{2}\left(a^{2}-r^{2}\right) \\
& \sigma=\frac{1}{4 \eta}\left(\frac{d p}{d z}\right)^{2}\left(2 r^{2}-a^{2}\right)
\end{aligned}
$$

液体の場合と同様にして，式(26)を用いて温度分布を求めると， 次式(27)を得る。

$$
T(r)= \begin{cases}T_{0}-\frac{\left(r^{2}-a^{2}\right)^{2}}{32 \eta \kappa_{f}}\left(\frac{d p}{d z}\right)^{2} & (0 \leqq r \leqq a) \\ T_{0} & (a \leqq r)\end{cases}
$$

一般の気体の場合，この不均一の大きさは，2 で述べた仮定を 満足する範囲では $10^{-4} \mathrm{~K}$ 以上にはなりえない。

以上の考察結果からみて, 気体の場合は粘性摩擦に上る発熱が 試料流体の温度に及ぼす影響については無視して差し支えないと 言える，気体の場合に，温度不均一をもたらす要因となりうるの は，むしろ流入端と管中に拈ける加速部分，括よび流出端に括け る減速部分での压力 (熱) エネルギーと運動エネルギーの間の変 換過程に伴 万温度の低下抽よび上畀である. 気体の粘度測定にお いては，この影響を許容誤差の大きさより小さくすることが重要 である，これらの管端効果等の問題は，本論文の範囲外である.

\section{3. 実験結果と考察}

2で得られた理論式の妥当性を検討するために，われわれの行 った実験の結果 ${ }^{5)}$ と理諭式による計算結果を比較してみる.

\section{$3 \cdot 1$ 実験}

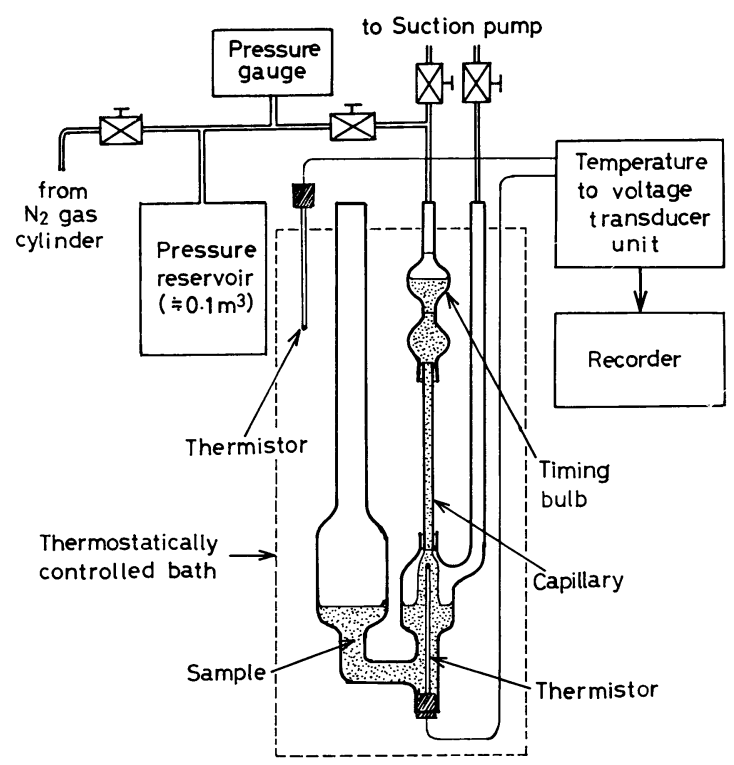

Fig. 3 A schematic diagram of a temperature rise measuring system, the main part of which is a variable-pressure type viscometer. 
実験に用いた装置の概要と橔院をFig. 3 に示す。测定には， 加压形の細管式粘度計を用い，粘度測定と温度上年量の測定を同 洔に行った。粘度計は自動制御式の恒温水槽内に罢き, $20^{\circ} \mathrm{C}$, $30^{\circ} \mathrm{C}, 40^{\circ} \mathrm{C}$ 谷温度の下で, 種々の站压 $0.5 \sim 2.5 \times 10^{5} \mathrm{~Pa}[0.5 \sim$

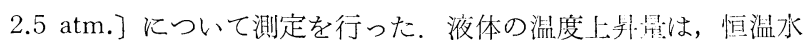
槽内温度と管流出端に抢ける温度の养をサーミスター鼬度計を用 いて測定して求めた。試料液体の粘度は, 粘度計本体の测時球 (Timing bulb) 上:下の棌線を液体表面が通恖する時間間隔より求 めた。陚料液体には, 二ュートン流体と見なせる鉱油を用いた。

\section{$3 \cdot 2$ 実験結果と理論式との比較}

実測值と理諭值との比較の結鼠をFig. 4 (a) および Fig. 4 (b)

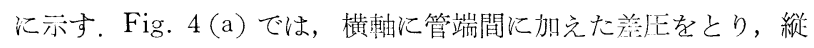
軸に管流出端に和ける温度上:非星をとった。测定結照を $\triangle(20$ $\left.{ }^{\circ} \mathrm{C}\right), \bigcirc\left(30^{\circ} \mathrm{C}\right)$ 㘧よび $\times\left(40^{\circ} \mathrm{C}\right)$ で示す。各温度について, 曲 線(1)は式(21)による結橗, 曲線(2)は式(18),(19)による結舆である。計 算に用いた細管と試料液体の各物性值はFig. 4(a)の中に記し

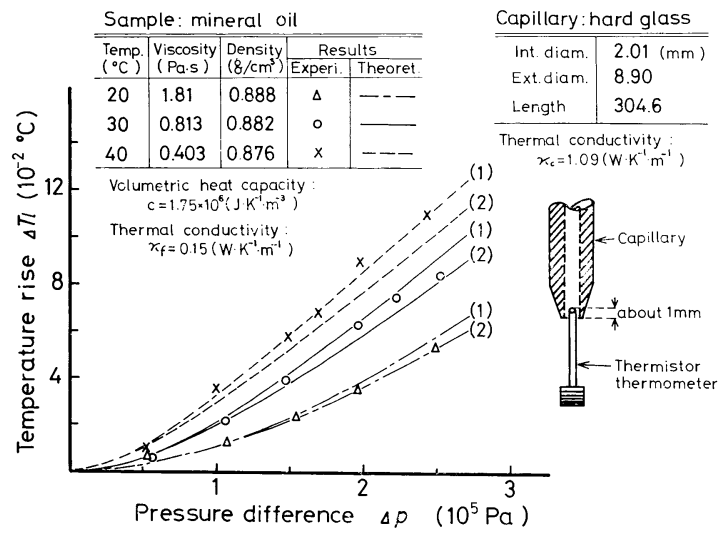

( a )

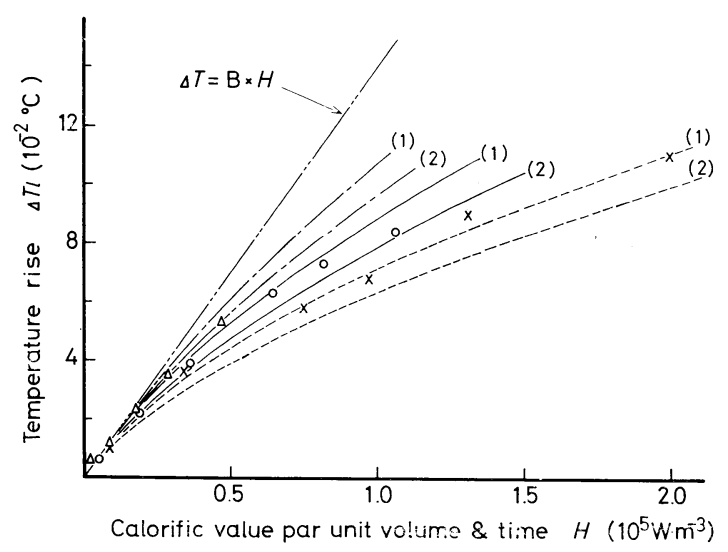

( b )

Fig. 4 Comparison between the experimental results (marks) and theoretical ones (curves); (a) representing the relation between the temperature rise at the exit end of tube $\Delta T_{l}$ and the pressure drop through tube $\Delta p$. The theoretical relations are obtained by eq. (21) for curve (1) and by eq. (18) and (19) for curve (2) ; (b) representing the relation between the temperature rise $\Delta T_{l}$ and the calorific value per unit volume and time $H$. The meanings of marks and curves are the same as in (a).

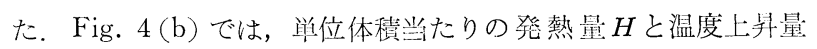
$\Delta T_{l}$ との関係を示す。実测值の印と理諭式の曲線との対応は, Fig. 4 (a) の場合と同じである。网中の曲線(1)は式(22)の理諭式に

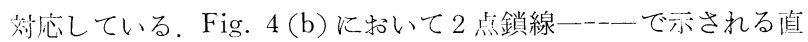

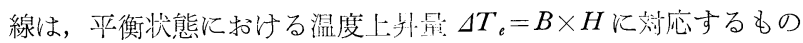
であり, この直線から外れる注ど平衡状態から外れた温度上等過 程にあることを意味している。発熱量 $H$ が小さい領域では, 理諭 曲線と実測值はともに平衡状態に溸近している。

\section{$3 \cdot 3$ 考察 \\ $3 \cdot 3 \cdot 1$ 理論式の比較}

Fig. 4(a) を見ると，理諭解について式(20)による結界（曲線(1)） と式(18)，(19)による結黑（曲線(2)）の間には最大で約11\%の相対差 がある、雨者の解の着の大きさについて検討する。この差は, $\Delta T_{c}$ に咕する $\Delta T_{f}$ の大きさの評価䛊着に原因するものであるか ら, 方!压功がさく, 流出流体温度 $\Delta T_{l}$ が, 正衡状態温度 $\Delta T_{e}$ 近くに筀している場合 $\left(\Delta T_{l} \doteqdot \Delta T_{e}\right)$ と, 加压力が充分大きく, 温度上:升過程の初期にある場合 $\left(\Delta T_{l} \ll \Delta T_{e}\right)$ には, 小さいはず である。この両状態の中間領域で，㭷刘差は大きくなる，差の大 きさは， $\Delta T_{e c}$ 飞咕する $\Delta T_{e f}$ の大きさ，すなわち $\Delta T_{e f} / \Delta T_{e c}$ の 大きさに依存し， $\Delta T_{e f} / \Delta T_{e c}$ が小さい汪ど美も小さくなる。本

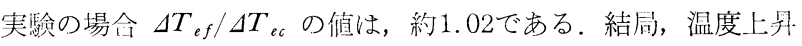
南の評価式として式(20)和よび(21)を用いるには， $\Delta T_{e f} / \Delta T_{e c}=(5 /$ $24) \times \kappa_{c} /\left(\kappa_{f} \ln (b / a)\right)$ の大きさが 1 程度以下であることを確かめ る必要がある。

\section{$3 \cdot 3 \cdot 2$ 系統誤差要因}

Fig. 4 亿示されているよ5に, 実測值と理諭式による計算值と の間には, 曲線(1)についても曲線(2)についても, 相刘偏差が最大 $10 \%$ 程度ある。温度 $20^{\circ} \mathrm{C}$ の場合には，実測值は曲線(2)にほぼ一致 し, 温度 $30^{\circ} \mathrm{C}$ の場合には実測值は曲線(1) と(2)の間に位置し, 温度 $40^{\circ} \mathrm{C}$ の場合には，実測值は曲線(1)飞注注一致している。これらの 䛊差の原因として系統的と考えられるものについて検討する.

（1）計算に用いた各物性值の5ちで，試料液体の熱容量 $c$ と熱

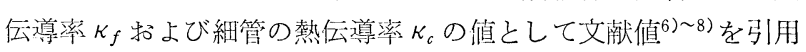

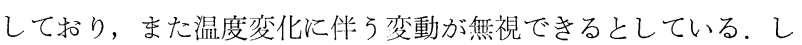
たがって, これら文献值と実際の值との間には, 相違があり光, この違いは直接計算結果の鿁差となって現れる。これらの值の温 度係数は, それぞれ $1 \times 10^{-3}\left[1 /{ }^{\circ} \mathrm{C}\right]$ 程度の大きさであり, $20^{\circ} \mathrm{C}$ の温度変化に唂して, 温度上年量 $\Delta T_{l}$ に現孔る变動量は, 大き くても $4 \%$ 程度である.

（2）２亿杍いて理諭解を得るために設けた仮定と，実験状態と の違いが無視しえない場合, 系統䛊差が生ずる. 特に, 仮定 7 (均一性) は，高登熱状態になる臣ど実際との差が大きくなる。 温度上界に伴弓粘度不均一の影響が最も大きいが，実験に招いて この大きさは $\mathbf{3} \cdot \mathbf{3} \cdot \mathbf{3}$ で述べるように $1 \%$ 以内だと考觉られる。

(3) 管流出端に拈ける液体の平均温度 $T_{a}$ とサ一ミスタ一温度 計による検出温度との間飞差が生ずることが考学られる。この差 の大きさは，管内に打ける $r$ 方向の温度不均一の大きさによって 決末ると思われ, 付録に見られるように不狗一の程度は, 平衡状 態からはずれるほど大きくなる傾向がある，よって高登熱の場合 ほどこの測定誤差は大きくなる。この誤差の大きさは, 測定位 置, 測定端子の大きさ, 棈造等化よっても変化するものと考兄ら れ，定量的に評価することは難しい。 


\section{$3 \cdot 3 \cdot 3 \quad$ 粘度測定に関連する問題点}

一般に，液体粘度は温度ととも減少するが，実験で用いた試 䊏の粘度の温度係数は約 $0.7 \times 10^{-1}\left[1 /{ }^{\circ} \mathrm{C}\right]$ である。 そのために。 管内流体が温度分柏を持つ場命, 粘度が不壮一になり, 流速分布 とともに登熱分布も㑐アズイ二流の場合からずれてくる，実騟に

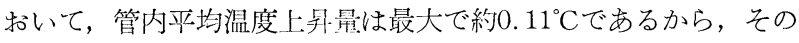
ときの粘度不均一は $0.8 \%$ 程度あると考穴られる。加压形粘度計 を用いて粘度測定をするには，この温度上年による誤差を測定精 度以内に怙さえる必要がある。そこで，理諭叔よび実駼の結界を 基にして，温度上䒜に関連する測定上の問題点をはっきりさせ る。

温度上昇量 $\Delta T_{l}$ と粘度 $\eta$, 加圧力 $\Delta p$ 扣よび管内径 $a$ 等の間の 関係については，式(20)より次のことが言光る。ここで，細管扣よ び試料の熱的性質が，常に同じであると仮定している。

（1）同一細管を用いるとき. 温度上最量 $\Delta T_{l}$ は平衡に落したと 仮定したときの温度上年量 $\Delta T$ 。の大きさと, 温度上升過程のどこ にあるかを示す量 $\Delta T_{l} / \Delta T_{e}$ の大きさによって沈まる。 $\Delta T_{e}$ は $\Delta p^{2} / \eta$ 飞比例しており， $\Delta T_{l} / \Delta T_{\text {。 }}$ は $/ \Delta p$ の大きさに依存し， $\eta / \Delta p$ が大きくなるほぞ，亚衡状態の 1 亿近づく，能率的な測定
をするには，测定時間をある积度以内に扣さえねばならないが， そのために $\Delta p \propto \eta$ となるように加に力を設定すると，上邈の関 係から温度上年景 $\Delta T_{l}$ は $\eta$ に比例する。 よって高粘度領域での測 定が闲雉になる。

(2) 管の内半径 $a$ を変えるとき，同一流唯を得るのに要する加 压力 $\Delta p$ は $\eta / a^{4}$ に比例している。 その压力下では, 温度上算量 $\Delta T_{l}$ は $\eta / a^{4}$ に比例する. よって高粘度領域に扔いては, 内永の比 輆的大きな細管を用いることにより温度上界を減らすことができ る。

以上の 2 点を考虑して，温度上䒜による䛊差を測定精度以内に 扣さえることを考えると，加圧形粘度計に扔いてもひとつの細管 で測定できる粘度範围は限られたものであり，広範团の粘度湘定 をするためては，適当な内径を持った複数の細管の組を用いる必 要があると䆚える。

おわりに，本渝文の執筆にあたり，有益な助言を頂いた計量研 宪所の川田裕郎第 4 部長, 抢よび有形無形の協力を頂いた第 3 部 レオロジー研究室の方々に深謝いたします。

（炤和53年10月24日，第26回レオロジー討諭会にて発表）

\section{List of Symbols}

\begin{tabular}{|c|c|c|}
\hline$a$ & : Internal radius of tube & $\mathrm{m}$ \\
\hline$b$ & : External radius of tube & $\mathrm{m}$ \\
\hline$c$ & : Volumetric heat capacity of fluid & $\mathrm{J} \cdot \mathrm{m}^{-3} \cdot{ }^{\circ} \mathrm{C}^{-1}$ \\
\hline$E$ & : External work performed by pressure per unit length & $\mathrm{W} \cdot \mathrm{m}^{-1}$ \\
\hline$H$ & : Calorific value by internal friction per unit volume & $\mathrm{W} \cdot \mathrm{m}^{-3}$ \\
\hline$l$ & Length of tube & $\mathrm{m}$ \\
\hline$L$ & Heat drain through tube wall per unit length & $\mathrm{W} \cdot \mathrm{m}^{-1}$ \\
\hline$m$ & : Molecular gas flow rate & $\mathrm{mol} \cdot \mathrm{sec}^{-1}$ \\
\hline$p(z)$ & : Pressure & $\mathrm{Pa}$ \\
\hline$\Delta p$ & : Pressure difference through tube & $\mathrm{Pa}$ \\
\hline$q$ & : Volumetric flow rate & $\mathrm{m}^{3} \cdot \mathrm{sec}^{-1}$ \\
\hline$Q$ & : Calorific value by internal friction per unit length & $\mathrm{W} \cdot \mathrm{m}^{-1}$ \\
\hline$r$ & : Radial distance & $\mathrm{m}$ \\
\hline$R$ & : Gas constant & $\mathrm{J} \cdot \mathrm{mol}^{-1} \cdot \mathrm{K}^{-1}$ \\
\hline$t$ & : Time & sec \\
\hline$T(r, z)$ & : Temperature & ${ }^{\circ} \mathrm{C}$ \\
\hline$T_{a}(z)$ & Average flow temperature $=\frac{2 \pi}{q} \int_{0}^{a} T u r d r$ & ${ }^{\circ} \mathrm{C}$ \\
\hline$T_{0}$ & : Outside temperature of tube & ${ }^{\circ} \mathrm{C}$ \\
\hline$\Delta T(z)$ & Average temperature rise of fluid $=T_{a}-T_{0}$ & ${ }^{\circ} \mathrm{C}$ \\
\hline$\Delta T_{e}$ & : Average temperature rise of fluid in equilibrium state & ${ }^{\circ} \mathrm{C}$ \\
\hline$\Delta T_{c}(z)$ & Temperature difference through tube wall & ${ }^{\circ} \mathrm{C}$ \\
\hline$\Delta T_{e c}$ & $\Delta T_{c}$ in equilibrium state & ${ }^{\circ} \mathrm{C}$ \\
\hline$\Delta T_{f}(z)$ & : Temperature difference between fluid and internal tube surface & ${ }^{\circ} \mathrm{C}$ \\
\hline$\Delta T_{e f}$ & : $\Delta T_{f}$ in equilibrium state & ${ }^{\circ} \mathrm{C}$ \\
\hline$\Delta T_{l}$ & : Average temperature rise of fluid at the exit end of tube & ${ }^{\circ} \mathrm{C}$ \\
\hline$u(r, z)$ & Velocity of fluid & $\mathrm{m} \cdot \mathrm{sec}^{-1}$ \\
\hline $\boldsymbol{w}$ & Thermal flow rate & $\mathrm{W} \cdot \mathrm{m}^{-2}$ \\
\hline$z$ & : Axial distance & $\mathrm{m}$ \\
\hline$\eta$ & : Viscosity of fluid & $\mathrm{Pa} \cdot \mathrm{sec}$ \\
\hline$\kappa$ & : Thermal conductivity & $\mathrm{W} \cdot \mathrm{m}^{-1} \cdot{ }^{\circ} \mathrm{C}$ \\
\hline
\end{tabular}




$\begin{array}{ll}\kappa_{c} & : \text { Thermal conductivity of tube } \\ \kappa_{f} & : \text { Thermal conductivity of fluid } \\ \sigma & : \text { Calorific value per unit volume } \\ \sigma_{v} & : \sigma \text { by internal friction } \\ \sigma_{p} & : \sigma \text { by adiabatical expansion }\end{array}$

文

1) Hersey, M.D., and J.C. Zimmer, J. Appl. Phys., 8, 359 (1937)

2) Bird, R.B., SPE J., 11, 35 (1955).

3) Toor, H.L., Ind. Eng. Chem., 48, 922 (1956).

4) Gee, R.E., and J.B. Lyon, Ind. Eng. Chem., 49, 956 (1957).

5）倉瀨公男，計量研究所報告， 25，3，10（1976）.

6）飯田他編, “物理定数表”, 90（1969）朝倉書店.

7）飯田他編，“物理定数表”，91（1969）朝倉書店.

8）東京天文台編，“理科年表”，物65（1978）丸善.

\section{付 録}

\section{管内温度分布の計算機による数值計算結果}

本文中の式(3) は $z$ 方向の熱伝導も考虑に入れた方程式である が，この式を評価式として，逐次近似法によって管内の温度分布 を求めた，計算に当たっては，管内を $100 \times 100$ つ配列に分割量子 化した．計算機は MELCOM COSMO-700を使用した。結界を Fig. A に示す．横軸に規格化した管径距離 $\rho=r / b$ をとり, 縦軸 に規格化した温度上界量 $\Theta=\Delta T / \Delta T$ ををとる。管流入端からの 距離は，本文中の式(20)飞怙ける $z_{02}$ を用いて $\zeta=z / z_{02}$ と規格化 してある。

平衡状態 $(\zeta \gg 1)$ 飞扮ける温度分布は, 本文中の式(13)で表され る解析解と一致するはずであるから，両者の分布の值を比較する

$\mathrm{W} \cdot \mathrm{m}^{-1} \cdot{ }^{\circ} \mathrm{C}$
$\mathrm{W} \cdot \mathrm{m}^{-1} \cdot{ }^{\circ} \mathrm{C}$
$\mathrm{W} \cdot \mathrm{m}^{-3}$
$\mathrm{~W} \cdot \mathrm{m}^{-3}$
$\mathrm{~W} \cdot \mathrm{m}^{-3}$

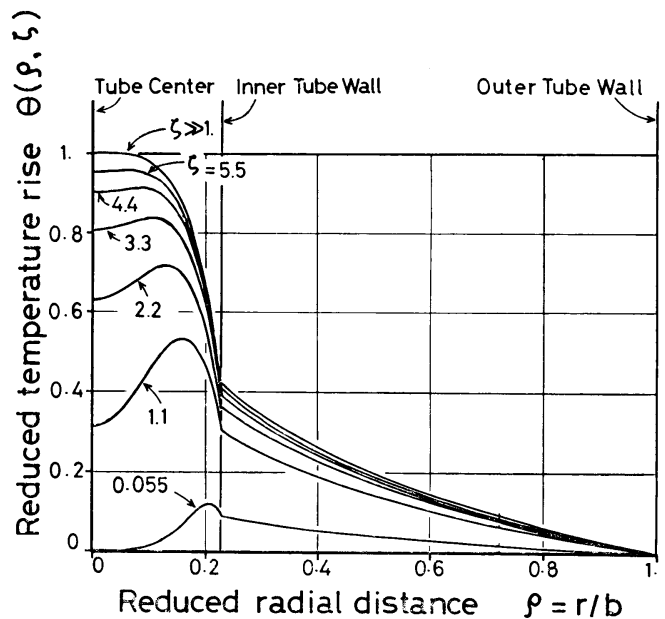

Fig. A Temperature distribution over the cross section of a tube, as a function of reduced axial distance $\zeta$ from the entrance end of a tube, calculated numerically with the iterative method applied to eq. $(3)^{\prime}$.

ことによりこの数值計算の信頼性を吟味することができる，両者 の相対䛊差は最大でも $2 \%$ 以内であり，管径方向 $r$ の量子化によ

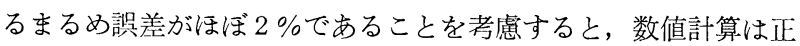
しく行われていると判断される。

数値計算によって得られた結果を基に $\Delta T_{f}$ と $\Delta T_{c}$ の関係を調 べてみると, 近似的に $\Delta T_{f} / \Delta T_{c} \propto \Delta T_{c}$ なる関係が認められる。 